\title{
Notes on the threatened lowland forests of Mt Cameroon and their endemics including Drypetes burnleyae sp. nov., with a key to species of Drypetes sect. Stipulares (Putranjivaceae)
}

\author{
Martin Cheek $^{1}$ (D), Nouhou Ndam² \& Andrew Budden ${ }^{1}$
}

Summary. This paper reports a further discovery of a new endemic threatened species to science in the context of botanical surveys in the lowland coastal forests of Mount Cameroon in the Cross River-Sanaga interval of westcentral Africa. These studies now focus on species discovery and conservation through the Tropical Important Plant Areas programme. New species to science continue to be discovered from Mt Cameroon. Most of these species are rare, highly localised, and threatened by habitat destruction, increasing the justification for improved conservation management of surviving habitat. Drypetes burnleyae is placed in and keyed out in Drypetes sect. Stipulares, a group mostly confined to Lower Guinea, here adjusted to accommodate nine species. The conservation status of Drypetes burnleyae is assessed as Endangered (EN B1+2ab(iii)) according to the 2012 criteria of the International Union for the Conservation of Nature. An updated overview of the plant endemics of Mt Cameroon is presented.

Key Words. Conservation, Cross-Sanaga Interval, South West Region Cameroon, Tropical Important Plant Area.

\section{Introduction}

The new species described in this paper as Drypetes burnleyae was brought to light as a result of botanical surveys to aid conservation management at and around Mount Cameroon (Cheek \& Hepper 1994; Cheek et al. 1996), long considered a Centre of Plant Diversity (Cheek et al. 1994). The species is a small tree or shrub, a near endemic of the coastal forests at the foot of Mt Cameroon.

In this paper we provide the evidence that this species is new to science, formally describe it, place it within the current classification of the genus, and review the ecology, endemics, conservation importance and threats to the largely unprotected coastal forest of Mt Cameroon in which it occurs.

\section{Putranjivaceae and Drypetes Vahl}

The family Putranjivaceae, formerly included in Euphorbiaceae, is considered to have up to three genera, Putranjiva Wall. (four species, restricted to Asia from India to New Guinea), Sibangea Oliv. (three species in tropical Africa) and the most species-diverse genus, Drypetes Vahl which is pantropical. Putranjiva and Sibangea are sometimes subsumed into Drypetes. Drypetes is considered to have about 200 species, with only c. 20 in the Americas, the remainder in Africa (c.
70 spp.) and Asia and Australasia (c. 100 spp. (Hoffmann 2007)).

Plants of the World Online (Plants of the World Online, continuously updated) gives 96 accepted names in Drypetes for 'Africa' but 15 of these are endemic either to Madagascar, Mascarenes, Comores or Seychelles, with two in Saõ Tomé, so about 79 taxa are accepted for continental Africa. Only five species occur in South Africa (e.g. D. natalensis (Harv.) Hutch.) while 25 species were accepted by Keay (1958) for Flora of West Tropical Africa. Cameroon with 31 species (if Sibangea is included) is the most speciesdiverse African country for Drypetes (Onana 2011) followed by Gabon with 26 species (Sosef et al. 2005).

Drypetes are evergreen, dioecious shrubs and small trees recognised by their alternate, distichous, more or less asymmetric, stipulate, often toothed leaves; and flowers which lack petals, and have $2-7$ unequal, imbricate sepals. The male flowers have $2-20(-50)$ free stamens with longitudinal dehiscence arranged around a central disc. In the female flower, stamens are absent and the pistil sits on the disc. Carpels are (1 -) 2 (-6), each with 2 axile ovules, which develop into drupaceous fruits (Hoffmann 2007: 144 - 146; Radcliffe-Smith 1987: 88).

In continental Africa, Drypetes species are mainly confined to the understorey of evergreen, usually lowland, forest. They are indicators of good quality

Accepted for publication 26 February 2021. Published online 14 June 2021

1 Royal Botanic Gardens, Kew, Richmond, Surrey, TW9 3AE, UK. e-mail: m.cheek@kew.org

2 Tetra Tech ARD - West Africa Biodiversity \& Climate Change (WA BiCC) Program PMB CT58, Accra, Ghana. 
(species-diverse, undisturbed forest), in the same way as are species of Cola (Cheek pers. obs. 1984 - 2012; Cheek 2002). Both genera are slow-growing shrubs and trees, not pioneers, and do not regenerate well after major forest disturbance. High species diversity in these genera at a site indicates forest of high conservation value in tropical Africa. Several species in Cameroon have small global ranges and have been assessed as threatened, e.g., Drypetes magnistipula Hutch. (EN), D. preussii Hutch. (VU), D. tessmanniana Pax \& K.Hoffm. (VU) (respectively Cheek 2004a, Cheek 2004b; Cheek \& Cable 2000) and once revisionary work is completed, the number of threatened species of Drypetes is expected to rise (Cheek in Onana \& Cheek 2011: 144).

Only three new species of Drypetes have been described in Africa in the $21^{\text {st }}$ century. These are D. moliwensis Cheek \& Radcl.-Sm. (Cheek et al. 2000a), D. bakembei D.J.Harris \& Wortley (2006) and D. morocarpa J.Léonard ex D.J.Harris \& Quintanar (Quintanar et al. 2020). This low number is partly because of the difficulty caused by the destruction of many German type specimens of Drypetes from Central Africa at B in 1943. Loss of this reference material especially hampers the elucidation of new Drypetes material from Central Africa because the former German colony of Kamerun (now the Republic of Cameroon) was the source of many if not most of these type specimens. It is also here that the genus is most species-diverse, and where discoveries of novelties are therefore still most likely. Currently, newly collected specimens of Drypetes often remain unidentified to species. In the Gabon checklist, while 146 specimens are identified to species, a further 147 remained unidentified (Sosef et al. 2005).

Burkill (1994: 54 - 60) reports on the uses of 19 species of Drypetes in the West African region. The wood of many species is reported as hard and durable, resistant to termites and is valued for constructing homes and mortars for pounding food. The fruits of several species are reported as edible and sometimes sold on markets. The majority of the uses reported are for treating a large variety of ailments, from toothache, wounds, internal and external parasites, fevers, rheumatism, boils and to relieve pain. Some species are used as fish or rat poisons. Johnson et al. (2009) report on the presence of "mustard oil" volatiles in Drypetes.

\section{Material and Methods}

The methodology for the surveys in which this species was discovered is recorded in Cheek \& Cable (1997). Nomenclatural changes were made according to the Code (Turland et al. 2018). Names of species and authors follow IPNI (continuously updated). Herbarium material was examined with a Leica Wild M8 dissecting binocular microscope fitted with an eyepiece graticule measuring in units of $0.025 \mathrm{~mm}$ at maximum magnification. The drawing was made with the same equipment with a Leica 308700 camera lucida attachment. Specimens were inspected from the following herbaria: BM, K, P, WAG, YA. The format of the description follows those in other papers describing new species in Drypetes e.g. Cheek et al. (2000a). All specimens cited have been seen unless indicated "n.v.". The conservation assessment follows the IUCN (2012) categories and criteria. GeoCAT was used to calculate red list metrics (Bachman et al. 2011). Herbarium codes follow Index Herbariorum (Thiers, continuously updated).

\section{Results}

The specimens on which the new species, Drypetes burnleyae, is based had been provisionally identified as "Drypetes ?principum" in preparation for publication of the Conservation Checklist for Mount Cameroon (Cable \& Cheek 1998). But, by oversight, they were not included in that work. Both species have large leaf-blades of similar size and shape and which dry dark brown on the lower surface and bear densely brown hairy fruits of about equal size from the leafy branches. However, the two species can be easily separated using the information in Table 1.

\section{Drypetes sect. Stipulares Pax \& K.Hoffm.}

A remarkable feature of Drypetes burnleyae are the large leathery persistent stipules. In most species of the genus the stipules are vestigial, triangular $<1 \mathrm{~mm}$ long and early caducous. Persistent stipules are only found in a minority of the species of the genus, most of which occur in West-Central Africa and which in the latest classification of the genus (Pax \& Hoffmann 1922) were grouped in sect. Stipulares. This section is characterised by medium to large persistent stipules 5 - 60 mm long, stamens 4 - 13 encircling a central disc which lacks a rudimentary ovary. In the female flowers the ovary is 2 (-3)-locular, lacks sculpture and is placed on a spreading disc. The stigmas are sessile or subsessile, dilated and undivided (Pax \& Hoffmann 1922). Drypetes burnleyae fits this description. A key to the species with persistent stipules is presented below. In this, our new species keys out in a couplet with D. similis (Oliv.) Hutch. This species was previously segregated with $D$. arborescens Hutch. as the genus Sibangea but was united with Drypetes by Hutchinson (1912) who also grouped these persistent-stipuled species together as his species $1-7$.

Pax \& Hoffmann(1922) followed Hutchinson in sinking Sibangea, but placed Drypetes similis in sect. Hemicyclia (Wight \& Arn.) Pax \& K.Hoffm. on account of the unilocular ovary, despite the large, persistent 
Table. 1. Characters differentiating between the similar species Drypetes principum and D. burnleyae. Data on the first species partly from Cheek (1992).

\begin{tabular}{|c|c|c|}
\hline & Drypete principum & Drypetes burnleyae \\
\hline Habit & Tree $(4-) 10-28 \mathrm{~m}$ tall & Tree or shrub $2.5-6 \mathrm{~m}$ tall \\
\hline $\begin{array}{l}\text { Indumentum and } \\
\text { colour (dried) of } \\
\text { distal stem nodes }\end{array}$ & $\begin{array}{l}\text { Distalmost } 1-4 \text { internodes drying matt black, } \\
\text { sparsely covered (c. } 10-20 \% \text { of surface) in } \\
\text { appressed red hairs }\end{array}$ & $\begin{array}{l}\text { Distalmost internode (below apical bud) completely } \\
\text { covered ( } 100 \% \text { of surface), in golden-brown appressed } \\
\text { hairs. Subsequent internodes with white glossy rapidly } \\
\text { glabrescent epidermis }\end{array}$ \\
\hline $\begin{array}{l}\text { Leaf-blade dimensions } \\
\text { and margins }\end{array}$ & $\begin{array}{l}12-22 \mathrm{~cm} \text { long, } 5-9 \mathrm{~cm} \text { wide, } \\
\text { margin with numerous teeth }\end{array}$ & $\begin{array}{l}(19.5-) 20.5-33(-40.2) \mathrm{cm} \text { long, } 6.5-11.4(-13) \mathrm{cm} \\
\text { wide, margin entire }\end{array}$ \\
\hline Stipules & $\begin{array}{l}\text { Minute, extremely caducous, triangular, } \\
<1 \mathrm{~mm} \text { long }\end{array}$ & $\begin{array}{l}\text { Conspicuous, persistent up to the fourth node below stem } \\
\text { apex, oblong to lanceolate, } 9-10 \times 3-4 \mathrm{~mm} \text {, leathery }\end{array}$ \\
\hline Male flowers & Stamens $8-12$ & Stamens 4 \\
\hline Stigmas in fruit & $\begin{array}{l}\text { Flat, obtriangular, } 3 \mathrm{~mm} \text { wide, } \\
\text { on styles } 1 \mathrm{~mm} \text { long }\end{array}$ & $\begin{array}{l}\text { Transversely oblong-ellipsoid (sausage-like), sessile, } \\
0.8-0.9 \mathrm{~mm} \text { long, } 1-1.25 \mathrm{~mm} \text { wide }\end{array}$ \\
\hline Indumentum of fruit & Patent, woolly appearance & Appressed to surface \\
\hline
\end{tabular}

stipules. We have added to this group Drypetes dinklagei (Pax) Hutch. since this species also has conspicuous persistent stipules which seem to have been overlooked by Pax \& Hoffmann (1922). It is possible that this group is a natural monophyletic unit. Apart from the traits listed by Pax \& Hoffmann (1922), these species are all geographically coherent, occurring from eastern Nigeria through Cameroon and Gabon, with some species ranging beyond, e.g. D. mildbraedii
(Pax) Hutch. in Democratic Republic of the Congo (DRC). These species also share leaves that completely or mainly lack, the marginal teeth that often characterise the genus, and have leaves that dry brown on the lower surface rather than grey-green. The last feature also occurs in some species outside the group, such as in D. principum. Molecular phylogenetic research is needed to test the monophyly of this group.

Key to the species of Drypetes with large, persistent stipules — Drypetes sect. Stipulares Pax \& K.Hoffm.

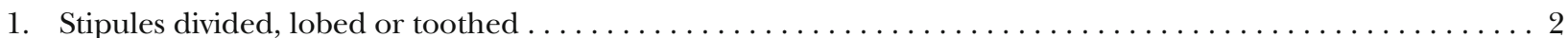

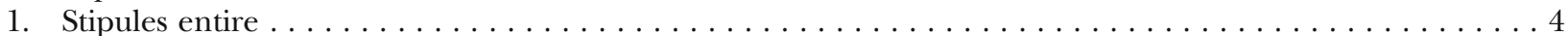

2. Stipules divided to the base into 2 or 3 linear segments; glabrous $\ldots \ldots \ldots \ldots \ldots \ldots \ldots$. . . . . . D. verrucosa

2. Stipules ovate-lanceolate or elliptic-oblong in outline, the two margins each with teeth, densely hairy. ...... 3

3. Stipules $10-19 \mathrm{~mm}$ long, laciniate, the segments $3-6$ on each side, linear or subulate, to $5-6 \mathrm{~mm}$ long; young stem terete $\ldots \ldots \ldots \ldots \ldots \ldots \ldots \ldots \ldots \ldots \ldots \ldots \ldots \ldots \ldots \ldots \ldots \ldots \ldots \ldots \ldots$

3. Stipules $6-9 \mathrm{~mm}$ long, oblong-lanceolate, the margins serrate with $1-3$ acute teeth $0.5-1 \mathrm{~mm}$ long; young

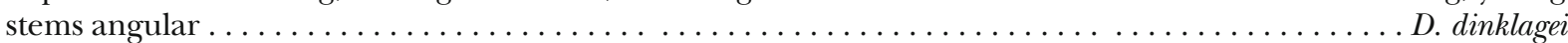

4. Stipules foliose, green, glabrous, ovate $20-30$ (-60) $\mathrm{mm}$ long, $10-20 \mathrm{~mm}$ wide, acute, cordate D. magnistipula

4. Stipules brown, papery or leathery-woody, hairy, narrowly ovate-lanceolate, narrowly oblong or triangular, 5 -

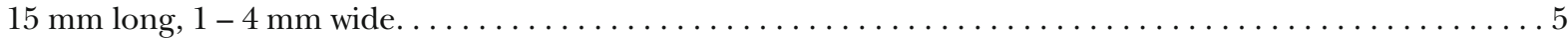

5. Stipules asymmetric, falcate-lanceolate; leaves $8.5-10 \mathrm{~cm}$ long, $3.2-4.5 \mathrm{~mm}$ wide. . . . . . . . D. bipindensis

5. Stipules symmetric, narrowly ovate-lanceolate, oblong, triangular; leaves $>10 \mathrm{~cm}$ long, $>4.5 \mathrm{~cm} \mathrm{wide} \mathrm{.} \mathrm{.} \mathrm{.} 6$

6. Stipules coriaceous, margins involute, with fine longitudinal folds $\ldots \ldots \ldots \ldots \ldots$

6. Stipules papery, margins flat, surface lacking folds $\ldots \ldots \ldots \ldots \ldots \ldots \ldots \ldots \ldots$

7. Pedicel 1.5 - 2 mm long; stigmas two, transversely oblong-ellipsoid; ovary bilocular.................. D. burnleyae

7. Pedicel 8 - $10 \mathrm{~mm}$ long; stigma single, umbonate; ovary unilocular. . . . . . . . . . . . . . . . D. similis

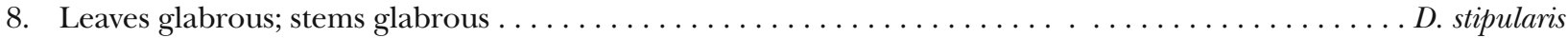

8. Leaves pubescent on the lower surface; stems pubescent $\ldots \ldots \ldots \ldots \ldots \ldots \ldots$

9. Male flowers with sepals 5 , inner surface glabrous . . . . . . . . . . . . . . . . . . . . D. molunduana

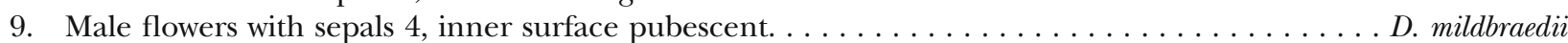

Drypetes burnleyae Cheek, sp. nov. Type: Cameroon, Southwest Region, on Hunters path to 'Lake Njonji',
40 minutes' walk $\mathrm{N}$ then $\mathrm{E}$ from $\mathrm{Njonji}, 4^{\circ} 08^{\prime} \mathrm{N}, 9^{\circ} 01^{\prime} \mathrm{E}$, alt. 150 - $300 \mathrm{~m}$, fr., 19 Nov. 1993, Cheek 5490 
(holotype: K barcode K000593141, isotypes: BR, K, MO, SCA, WAG, YA).

http:/ /www.ipni.org/urn:lsid:ipni.org:names:77216911-1

Dioecious tree or shrub $2.5-6 \mathrm{~m}$ tall, trunk $4-7 \mathrm{~cm}$ diam. at $1.5 \mathrm{~m}$ from the ground, bark grey. Fruiting and flowering from burrs on the leafy stems. Leafy stems distichous, densely golden hairy completely covering terminal internode of stem apex, rapidly caducous at the internodes below, hairs simple, $0.05-$ $0.2 \mathrm{~mm}$ long appressed; epidermis below the first node longitudinally furrowed, grey white or white, glossy, often c. $50 \%$ covered in micro-epiphytes, lenticels developing from c. fourth internode, white, slightly raised, elliptic $1-2 \mathrm{~mm}$ long, c. $0.5-1 \mathrm{~mm}$ wide; internodes even in length $2.1-5.8(-6.3) \mathrm{cm}$ long, diam. $0.3-0.35 \mathrm{~cm}$ at the fourth internode from apex, stems slightly flexuose, or terete, with up to 8 leaves per stem. Leaf-blades drying grey-green above, brown below, narrowly oblong-elliptic, rarely slightly oblanceolate-oblong, $(19.5-) 20.5-33(-40.2) \times 6.5-$ $11.4(-13) \mathrm{cm}$, acumen $0.4-1.1(-1.4) \mathrm{cm}$ long, acute, base acute, inconspicuously asymmetric, margin entire, lateral nerves $(7-)$ 8-11 (-12) on each side of the midrib, drying black, arising at $45^{\circ}$ from the midrib, arching upwards distally, then running parallel to the margin and connecting with the secondary nerve above by $3-4$ brown tertiary nerves, sometimes with a short brown intersecondary nerve present; quaternary nerves brown (concolorous with blade) forming a reticulate pattern, conspicuous on abaxial surface, glabrous. Petiole drying grey, slightly laterally compressed, adaxial surface slightly and shallowly grooved or not, surface longitudinally wrinkled, $(0.7$ -) $0.9-1.3 \times 0.2 \mathrm{~cm}$, glabrous. Stipules persisting to the fourth node below stem apex, coriaceous, grey-brown, lanceolate or oblong-lanceolate, $(7-) 8-10 \times(2-) 3-$ $3.5 \mathrm{~mm}$, apex long tapering, acute, margins revolute, surface finely longitudinally furrowed, indumentum as stem apices. Female inflorescences in axillary fascicles subtended by the most distal (oldest) leaves from the apex or sometimes at leafless nodes, 1 - 8-flowered, each flower subtended by a bract and pair of bracteoles. Bracts concave, brown, ovate-elliptic $1.5-$ $1.75 \mathrm{~mm}$ long $1-1.25 \mathrm{~mm}$ wide, apex acute, completely covered in appressed, yellow-brown hairs, hairs simple, 0.125 - $0.175 \mathrm{~mm}$ long; bracteoles triangular, 0.75 - $1 \mathrm{~mm}$ long and wide, indumentum as bracts. Female flower "with pale yellow ovary and narrow white annular disc" (Thomas 9710), $5-7.5 \mathrm{~mm}$ long, $3.2-3.5 \mathrm{~mm}$ wide, pedicel $1.5-2 \mathrm{~mm}$ long, 0.8 $1 \mathrm{~mm}$ diam., indumentum as bracts. Outer sepals 2, concave, elliptical 3.5 - $4 \mathrm{~mm}$ long, $2.8-3.8 \mathrm{~mm}$ wide, apex rounded, outer and inner surface densely covered (90 - 100\% of epidermis covered) in indumentum as in the bracts, but hairs $0.25 \mathrm{~mm}$ long.
Inner sepals 2, ovate-elliptic, $5.5 \mathrm{~mm}$ long, 4.8 $5.5 \mathrm{~mm}$ wide, apex and indumentum as outer sepals. Disc protruding beneath ovary by $0.25 \mathrm{~mm}, 1.25 \mathrm{~mm}$ high, rounded, entire, glabrous. Ovary ovoid 5.5 $6 \mathrm{~mm}$ long, 4.7 - $6 \mathrm{~mm}$ wide, lacking grooves, completely covered in appressed yellow-brown hairs c. $0.25 \mathrm{~mm}$ long; 2-locular. Stigmas 2, black, sessile, parallel, transversely oblong-ellipsoid, $0.8-0.9 \mathrm{~mm}$ long, $1-1.25 \mathrm{~mm}$ wide. Male inflorescences as the female, 1 - 7-flowered. Male flowers "Calyx light green" (Tchouto 687) 4 - $4.5 \mathrm{~mm}$ long, 2.5 - $3 \mathrm{~mm}$ wide at anthesis, opening from globose buds. Pedicel 1.5 $2 \mathrm{~mm}$ long, $0.5-0.7 \mathrm{~mm}$ diam., indumentum as in females. Outer sepals 2, concave, ovate-elliptic, $3.5-$ $4 \mathrm{~mm}$ long, $4 \mathrm{~mm}$ wide, apex rounded, indumentum as females covering $20-70 \%$ of surface. Inner sepals 2, orbicular $3 \mathrm{~mm}$ long, $3 \mathrm{~mm}$ wide, indumentum as in females, $90 \%$ cover. Stamens 4 , not exserted, $1-1.4 \mathrm{~mm}$ long, filaments stout, $0.4 \mathrm{~mm}$ long, glabrous, anthers orbicular, $1 \mathrm{~mm}$ long, $1 \mathrm{~mm}$ wide, dorsal face flattened, ventral with 4 longitudinal thecae, apex rounded, apex with $2-3$ tufts of hairs $0.5 \mathrm{~mm}$ long, margin fringed with hairs. Disc flat, glabrous, rounded-quadrangular $1.75 \mathrm{~mm}$ diam., each of the 4 edges with a shallow notch (accommodating an anther filament), upper surface with raised coarse reticulations, cells c. $0.2-0.3 \mathrm{~mm}$ diam. Rudimentary ovary absent. Fruit ellipsoid, (1.2 -) $1.4-1.9 \mathrm{~cm}$ long, $0.8-0.9(-1) \mathrm{cm}$ diam., with 2 opposite shallow longitudinal grooves when dry, completely covered in appressed whitish brown hairs. Stigmas persistent, not accrescent. Pedicel accrescent $(0.15-) \quad 0.2-0.4 \mathrm{~cm}$ long. Sepals persistent, not accrescent. Seeds 2, one per locule, dark brown, planoconvex, $16 \mathrm{~mm}$ long, $10 \mathrm{~mm}$ wide, $6 \mathrm{~mm}$ broad, lacking surface ornamentation. Fig. 1.

RECOGNITION. Differing from Drypetes principum Hutch. in the conspicuous, persistent, large $(9-10 \times 3-4$ $\mathrm{mm}$ ) leathery stipules (vs stipules inconspicuous, caducous, small, <1 mm long); distalmost internode completely covered in golden hairs, subsequent nodes glabrous, white (vs with all the distal nodes drying black, sparsely covered in red hairs); stigmas sessile,

Fig. 1. Drypetes burnleyae. A habit including fruiting shoot, outline of larger leaf in background; B stem apex; $\mathbf{C}$ detail of hairs at *; $D$ detail of hairs at $\Psi$; $E$ pair of stipules; $F$ male flower, side view (hydrated); $G$ male flower in $F$ with outer sepals removed and front inner tepal reflexed to show stamens; $\mathrm{H}$ disc from $\mathrm{F}$ viewed from above; J stamen, outer face; $K$ stamen, inner face; $L$ female flowers in situ (dry) with view of stigmas from above; $M$ side view of young fruit in situ (hydrated) [hairs on inner and outer faces of sepals omitted]; N fruits in situ; $\mathrm{P}$ hairs from fruit surface; $\mathrm{Q}$ mature fruit, TS (hydrated). A - E, L, N - Q from Cheek et al. 5490 (K). F - K from Tchouto 687 (K). M from Ndam 754 (K). DRAWN BY ANDREW BROWN . 


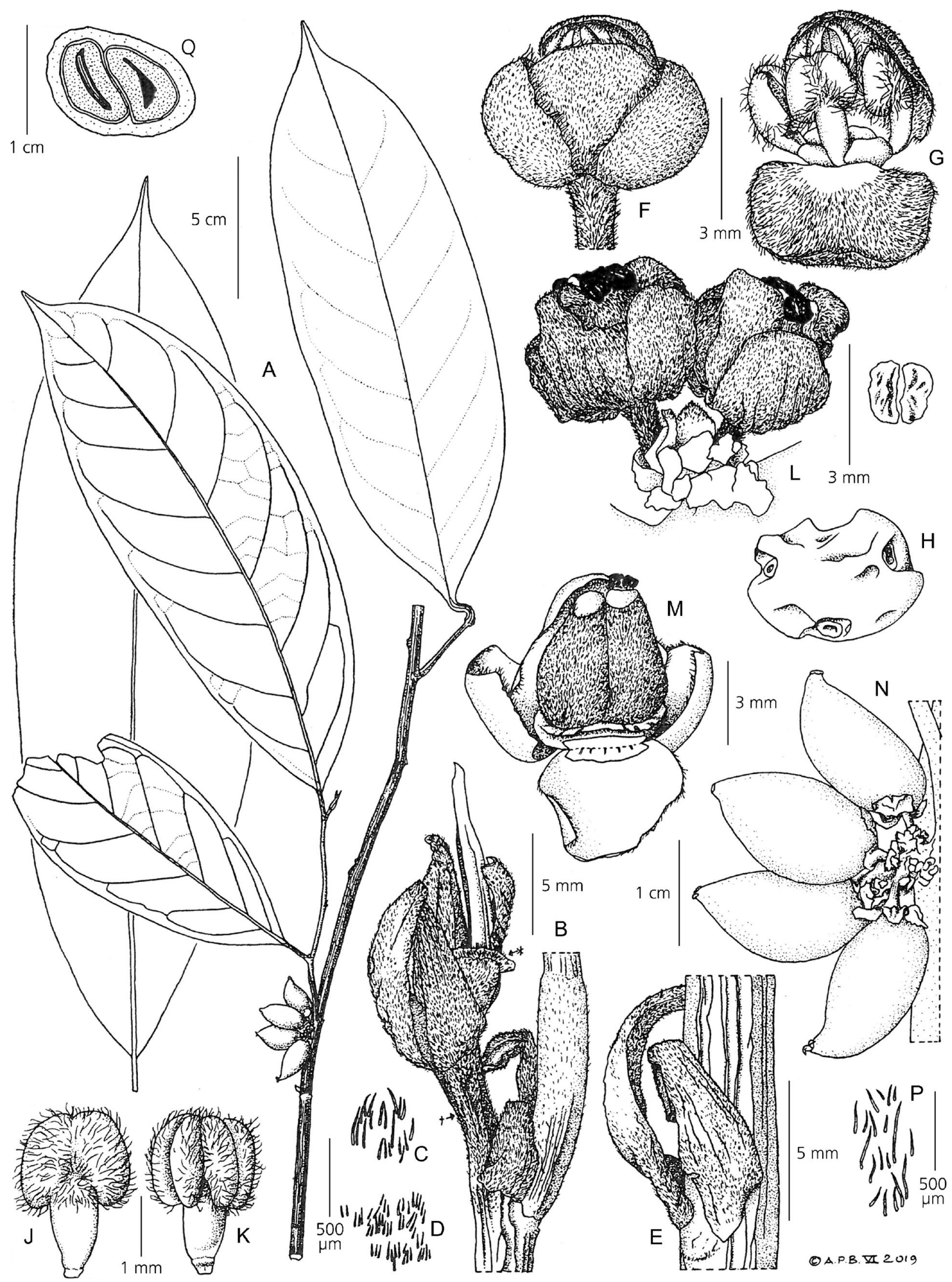




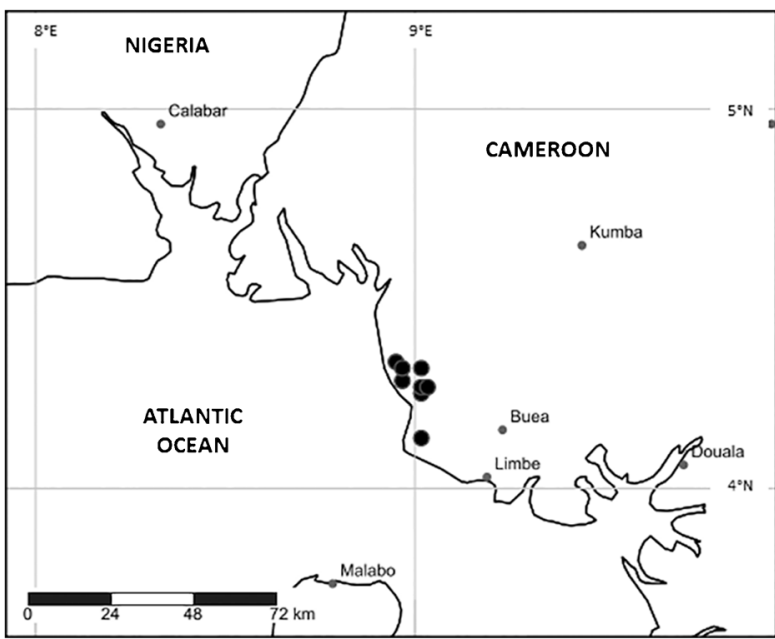

Map 1. Distribution of Drypetes burnleyae.

transversely oblong-ellipsoid (vs stalked, flat and obtriangular). For additional characters see Table 1.

DISTRIBUTION. Cameroon, South West Region (Map 1). So far only known from coastal forest of Mt Cameroon.

SPECIMENS EXAMINED. CAMEROON: South West Region (formerly Province), Mount Cameroon, Onge Forest, Bomana-Koto road c. $500 \mathrm{~m}$, bearing $305^{\circ}$ towards Onge R., $5 \mathrm{hr}$ walk from the road, $4^{\circ} 19^{\prime} \mathrm{N}, 9^{\circ} 01^{\prime} \mathrm{E}, 400$ m alt., fl., fr., 20 Oct. 1993, Ndam 754 (K, SCA n.v., YA n.v.); Bomana-Koto road c. $500 \mathrm{~m}$, bearing $305^{\circ}$ towards Onge R., $3 \mathrm{hr}$ walk from the road, $4^{\circ} 19^{\prime} \mathrm{N}$, $9^{\circ} 01$ 'E, $400 \mathrm{~m}$ alt., fl., fr., 18 Oct. 1993, Ndam 681 (K, SCA n.v.); Southwest Region, Bomana secondary forest, $04^{\circ} 15^{\prime} \mathrm{N}, 09^{\circ} 01$ 'E, $200 \mathrm{~m}$ alt., fr., 5 Oct. 1993, Tchouto Mbatchou 687 (K, SCA n.v., YA n.v.); Bomana secondary forest, $4^{\circ} 15^{\prime} \mathrm{N}, 9^{\circ} 1$ 'E, $200 \mathrm{~m}$ alt., 6 Oct. 1993 , Tchouto Mbatchou 706 (K, SCA n.v.); Onge R. secondary forest, $4^{\circ} 16^{\prime} \mathrm{N}, 9^{\circ} 1^{\prime} \mathrm{E}, 240 \mathrm{~m}$ alt., 9 Oct. 1993, Tchouto Mbatchou 706 (K, SCA n.v.); Southwest Region, 0.5 km $\mathrm{W}$ of the Idenao-Bomana road, in a ravine formed by the Lokange R., $4^{\circ} 16^{\prime} \mathrm{N}, 9^{\circ} 02^{\prime} \mathrm{E}, 100 \mathrm{~m}$ alt., fl., fr., 6 Oct. 1993, Thomas 9710 (K, SCA n.v., YA n.v.); West bank of the Onge R., $4^{\circ} 17^{\prime} \mathrm{N}, 8^{\circ} 58^{\prime} \mathrm{E}, 100 \mathrm{~m}$ alt., 7 Nov. 1993, Thomas 9809 (K, SCA n.v.); Forested hillside $\mathrm{W}$ of the Onge $\mathrm{R}$. and ridges on "Thump Mount", $4^{\circ} 20^{\prime} \mathrm{N}, 8^{\circ} 57^{\prime} \mathrm{E}, 200 \mathrm{~m}$ alt., fr., 9 Nov. 1993, Thomas 9868 (K, SCA n.v.); Forest to the W of Onge R., c. $6 \mathrm{~km}$ along the Onge R. from its mouth and c. $8 \mathrm{~km}$ $\mathrm{NW}$ of Idenau, $4^{\circ} 19^{\prime} \mathrm{N}, 8^{\circ} 58^{\prime} \mathrm{E}, 100 \mathrm{~m}$ alt., 11 Nov. 1993, Watts 1029 (K, SCA n.v.).

HABITAT. Infrequent small tree or shrub of undisturbed lowland evergreen forest on old volcanic or pre-Cambrian rocky soils; $50-300 \mathrm{~m}$ alt.

CONSERVATION STATUS. Drypetes burnleyae has an extent of occurrence of $94 \mathrm{~km}^{2}$ and area of occupancy of 32 $\mathrm{km}^{2}$ as calculated using GeoCAT (Bachman et al. 2011). There are only three "threat-based" locations
(IUCN 2012), in the Onge forest and the BomanaNjonji forest. These areas of Mount Cameroon are threatened with forest clearance, both for timber and oil palm. Species within the genus Drypetes are slow growing trees and shrubs and are indicators of good quality, undisturbed forest. They do not regenerate well after major forest disturbance and are therefore especially sensitive to the threats posed by forest clearance. Given the threats and restricted range, an assessment of Endangered (EN B1+2ab(iii)) is given to this species.

ETYMOLOGY. Named in honour of Mrs Gwendoline Etonde Burnley (1932 - 2020) of Limbe (formerly Victoria), the first anglophone female MP of Cameroon, and UN delegate for Cameroon. She championed the cause of restoring the Limbe Botanic Gardens as part of the UK Government-supported Mount Cameroon Project that sought to protect the world-renowned plant diversity of Mt Cameroon. Until recently, she was Chair of the Friends of the Limbe Botanic Garden.

NOTES. Drypetes burnleyae may yet be discovered to have a wider range than $\mathrm{Mt}$ Cameroon. Several other species previously considered endemic to the mountain have since been found in other locations (see discussion on endemics of Mt Cameroon below). However, following the intensive survey at Mt Cameroon (Cable \& Cheek 1998) during which the specimens cited above of Drypetes burnleyae were collected, surveys of other areas in Cameroon followed, for example at Korup National Park (Cheek \& Cable 1998), Mt Kupe and the Bakossi Mts (Cheek et al. 2004), in the Lebialem Highlands (Harvey et al. 2010), the Bali Ngemba Forest Reserve (Harvey et al. 2004), at Mefou proposed National Park (Cheek et al. 2011) at Dom (Cheek et al. 2010) and at Ebo (Cheek et al. 2018a). Yet no further sites for Drypetes burnleyae were found.

\section{Mt Cameroon, its endemic plants and its coastal forests}

At 4095 m high, Mt Cameroon, locally known as Fako, is by far the highest mountain, and the only active volcano, in continental West-Central Africa. One has to travel about $1300 \mathrm{~km}$ eastwards to the Virunga Mts of eastern DRC before encountering mountains of comparable height, or active volcanoes. Fako erupts roughly every 20 years and the last lava flow dates from May 2000.

Rainfall varies dramatically from one part of the mountain to another, most falling in the $8-9$ month wet season between April to November. There are no months with less than $50 \mathrm{~mm}$ precipitation at Cape Debundscha, on the SW, seaward side, which receives 10 - $15 \mathrm{~m}$ p.a., but at Tiko to the $\mathrm{E}$ there are two months with $<50 \mathrm{~mm}$, and rainfall declines to $2-3 \mathrm{~m}$ 
p.a. while at the summit and in the rainshadow to the $\mathrm{E}$, it is $1-2 \mathrm{~m}$ per year (Courade 1974).

The volcanic massif is about $45 \mathrm{~km}$ along its longest axis, SSW - NNE, and $28 \mathrm{~km}$ across at its narrowest (Cable \& Cheek 1998). Together with the foothill areas and lower slopes that surround it, it has the highest documented species diversity for vascular plants in tropical Africa, with 2435 species, of which 49 have been considered strict endemics and of which 116 were reported as threatened (Cable \& Cheek 1998). However, numerous additional new species, several endemic, have been published in the last 20 years.

Botanical exploration of Mt Cameroon began in 1861 with the Kew botanist Gustav Mann, resulting in the remarkable paper on the high-altitude Flora of the mountain (Hooker 1864). Numerous other botanists including Preuss, Schlechter, Mildbraed, Kalbreyer, Dusen, Maitland, Brenan and Letouzey followed Mann in increasing knowledge of the plants of this mountain (Cable \& Cheek 1998).

The Mount Cameroon National Park was created in 2009 , to a large degree because of its unique botanical importance. The mountain is a tourist attraction, particularly for those who wish to walk to the summit from the former German colonial capital of Buea on the eastern slope of the massif. Forest elephants and the endemic Mt Cameroon Francolin (Pternistus camerunensis) are also attractions, although rarely seen.

Arguably the most spectacular botanical discovery at Mount Cameroon, from its northern foothills, the Southern Bakundu Reserve, was that of Medusandra richardsiana Brenan, basis of a new family, the Medusandraceae (Brenan 1952), to which was later added the genus Soyauxia Oliv. Medusandraceae sensu stricto (Medusandra Brenan) was until recently considered endemic to the Cross-Sanaga interval (Heywood 2007). Subsequently, however, both Soyauxia and later Medusandra were shown to be confamilal with the rare and little known South American family, Peridiscaceae (Soltis et al. 2007; Breteler et al. 2015). The CrossSanaga interval (Cheek et al. 2001), comprising largely of South West Region, Cameroon, contains the area with the highest species diversity per degree square in tropical Africa (Barthlott et al. 1996; Cheek et al. 2006), and many of these species are narrow endemics, and a large number are at Mt Cameroon.

The emphasis of the UK government Mt Cameroon Plant Genetic Resources Project, later known as the Mount Cameroon Project was to focus on conservation management of the forest plant diversity, especially the highly threatened lowland forest vegetation. Following rehabilitation of the Limbe Botanic Garden, its base, the project conducted surveys in the eastern foothills formerly known as Mabeta-Moliwe (Cheek 1992) now known as Bimbia-Bonadikombe, and then of the Etinde area (Thomas \& Cheek 1992), and in the coastal forests between Idenau and Limbe, with the adjoining coastal eastern foothill forest of Onge (late 1993) and finally Mokoko forest (early 1994). Following identifications, a checklist for Mt Cameroon and its foothills was published (Cable \& Cheek 1998). The specimens of Drypetes burnleyae cited in this paper were collected during these surveys.

Several Mount Cameroon endemics occur above $2000 \mathrm{~m}$ alt. both at the forest-grassland ecotone or in the montane grassland above that begins the summit area. These include Silene biafrae Hook.f. (Hooker 1864), Myosotis cameroonensis Cheek \& R.Becker (Cheek \& Becker 2004) and Luzula mannii (Buchenau) Kirschner \& Cheek subsp. mannii (Kirschner \& Cheek 2000). Yet some species among the nine previously listed as endemic to this summit area (Cable \& Cheek 1998) are now known to have a wider distribution. Both Genyorchis macrantha Summerh. and also, Isoglossa nervosa C.B.Clarke have subsequently been found on another peak in the Cameroon Highlands, Mt Oku (Darbyshire et al. 2011), which at $3095 \mathrm{~m}$ alt., is also a centre of plant diversity of conservation importance (Maisels et al. 2000; Cheek et al. 2000b). Yet a greater number of the Mt Cameroon endemics are found in the submontane or cloud forest that extends from c. $800-2000 \mathrm{~m}$ altitude (Tchouto et al. 1999; Thomas \& Cheek 1992). Eleven are listed in Cable \& Cheek (1998), several of which were only formally named and published subsequently. These include Oxygyne duncanii Cheek (Cheek et al. 2018a), Impatiens etindensis Cheek \& Eb.Fisch (Cheek \& Fischer 1999), Impatiens frithii Cheek (Cheek \& Csiba 2002) and orchids such as Angraecopsis cryptantha P.J.Cribb (Cribb 1996). However, most of the Mt Cameroon endemics and the most threatened species overall, are found in the evergreen lowland forest that survives in the foothills and in coastal areas below $800 \mathrm{~m}$ altitude.

Twenty-nine species of lowland endemics are listed by Cable \& Cheek (1998: xxxii) of which 17 were newly discovered and still awaited publication at that time. Subsequently, some of these supposed endemic species were either synonymised, e.g., Trichoscypha camerunensis Engl. or found to have wider distributions, e.g., Trichoscypha bijuga Engl. (Breteler 2004). Some of those subsequently published as new to science and thought to be endemic, such as Salacia nigra Cheek (Gosline et al. 2014) and Belonophora ongensis S.E.Dawson \& Cheek, were later found to extend beyond Mt Cameroon to Littoral Region (Cheek et al. 2018b; Cheek \& Dawson 2000). This was also the case with Stelechantha arcuata S.E.Dawson (2002) now Pauridiantha arcuata (S.E.Dawson) Smedmark \& B.Bremer (2011) which extends to Mt Kupe and the Bakossi Mts (Cheek et al. 2004), Psychotria elephantina O.Lachenaud \& Cheek (Cheek \& Lachenaud 2013) extending to Korup (Lachenaud 
2019), and also, Ancistrocladus grandiflorus Cheek (2000), subsequently found to extend to the Rumpi Hills.

However, other endemics recorded for $\mathrm{Mt}$ Cameroon in Cable \& Cheek (1998), under working names that were formalised later, remain strictly endemic to the coastal lowland forests such as Cola cecidifolia Cheek (2002), Psychotria bimbiensis Bridson \& Cheek (Cheek \& Bridson 2002) and Drypetes moliwensis Cheek \& Radcl.-Sm. (Cheek et al. 2000a). Reexamination of specimens collected in the surveys of the 1990s has uncovered further endemic new species, not listed as such in Cable \& Cheek (1998), such as Dracaena mokoko Mwachala \& Cheek (2012) and Octoknema mokoko Gosline \& Malécot (2012). Aframomum tchoutoui D.J.Harris \& Wortley is an example of one of several near-endemics discovered in the same way, in this case extending about $50 \mathrm{~km}$ west and $100 \mathrm{~km} \mathrm{~N}$ of Mt Cameroon (Harris \& Wortley 2018). New surveys at Mt Cameroon in the $21^{\text {st }}$ century have discovered other highly threatened species entirely overlooked in the 1990s, such as Kupea martinetugei Cheek (Cheek et al. 2003), Psychotria asterogramma O.Lachenaud (2019), and a further new endemic, Afrothismia foertheriana, T.Franke, Sainge \& Agerer (Franke et al. 2004).

The rarest of the rare endemic Mt Cameroon plant species were considered those nine species listed as possibly extinct globally in Cable \& Cheek (1998) since they had not been seen for over 60 years (now 80 years), not being found in the surveys of the 1990s. Eight of these species were lowland forest endemics. In one case, Coleus dissitiflorus Gürke (treated as Plectranthus dissitiflorus (Gürke) J.K.Morton in Cable \& Cheek (1998)), a collection was discovered from the 1970 s giving hope that it survives today. But the remainder have not been seen, leading to fears that they are indeed extinct. In one case, Oxygyne triandra Schltr., a series of concerted efforts were made to rediscover it over several years, without success, leading to the conclusion that it is indeed now globally extinct (Cheek \& Williams 1999; Cheek et al. 2018a). This is also the case with a further mycotroph, Afrothismia pachyantha Schltr., that had been collected with the Oxygyne. This Afrothismia was thought to have been locally extinct at Mt Cameroon but was mistakenly considered to have been rediscovered on $\mathrm{Mt}$ Kupe (Cheek 2004c), until the Mt Kupe population was found to be a separate species rendering Afrothismia pachyantha restricted to the lowland forest of Mt Cameroon and also globally extinct (Cheek et al. 2019).

The habitat of all these coastal lowland forest species falls outside the Mount Cameroon National Park which is restricted to higher altitudes. Lowland forest and its species are undoubtedly the most threatened at Mt Cameroon. Clearance of coastal forest had begun in the eastern foothills area of Mabeta by the early $19^{\text {th }}$ century to produce food for slaves being held at Bimbia by the Isuwu. Later the Christian settlement of Victoria (now Limbe) was founded in 1858 at Ambas Bay by Alfred Saker of the London Missionary Society. More extensive forest clearance began with the advent of the German colony of Kamerun (now Cameroon) in 1884. The fertile volcanic soils and abundant rainfall merited extensive lowland forest clearance to support plantation crops for export to Europe, initially of bananas, later of rubber and oil palm. Oil palm plantation now extends in a belt around the seaward southern base of Mount Cameroon from Cameroon's largest port, Douala, but does not yet occupy the more infertile western foothill areas. Today, the lowland forest areas that remain are threatened by clearance for timber, followed by subsistence agriculture and plantation expansion. Limbe is now a city, and a port, with an oil refinery and a population of about 118,000 persons (Cameroon data portal 2015).

These threats make it a priority to name $\mathrm{Mt}$ Cameroon coastal forest endemic species such as Drypetes burnleyae, since until this is done, conservation assessments are not accepted by IUCN (IUCN 2012), and as a result, proposals for conservation measures are less likely to be enacted.

The number of flowering plant species known to science is disputed (Nic Lughadha et al. 2017), but of the estimated 369,000 vascular plant species known (Nic Lughadha et al. 2016), only $7.2 \%$ are included on the Red List using the IUCN (2012) standard (Bachman et al. 2019). About 2000 new species are still discovered each year (Cheek et al. 2020), and a high proportion of these are likely to be threatened, since more widespread species tend already to have been discovered, although there are exceptions (Cheek \& Etuge 2009). This makes it all the more urgent to find, document and protect undescribed species before they become globally extinct, as have the eight species discussed above from $\mathrm{Mt}$ Cameroon.

Efforts are now being made to delimit the highest priority areas in Cameroon for plant conservation through the Tropical Important Plant Areas (TIPAs): Cameroon programme (Cheek, continuously updated) which uses the revised Important Plant Areas (IPA) criteria set out in Darbyshire et al. (2017). The coastal forests of Mt Cameroon, the habitat for Drypetes burnleyae will be among the TIPAs so designated.

\section{Acknowledgements}

This paper was completed as part of the Cameroon TIPAs (Tropical Important Plant Areas) project at RBG, Kew, which is supported by Players of People's 
Postcode Lottery. Janis Shillito typed the manuscript. George Gosline and two anonymous reviewers gave advice on an earlier version of the manuscript. Fieldwork funding in the 1990s leading to the discovery and collection of most of the specimens cited in this paper was received from the former Overseas Development Administration (ODA) of the UK government (now incorporated in the Foreign, Commonwealth and Development Office) through the former Mount Cameroon Project at Limbe Botanic Garden, which was co-managed by ODA with the Forest Department of the Cameroon Government. The fieldwork during which the type collection was collected was supported by the Earthwatch Institute. The authors thank Dr Jean Michel Onana of Yaoundé and an anonymous reviewer for constructive comments on an earlier version of this manuscript.

Open Access This article is licensed under a Creative Commons Attribution 4.0 International License, which permits use, sharing, adaptation, distribution and reproduction in any medium or format, as long as you give appropriate credit to the original author(s) and the source, provide a link to the Creative Commons licence, and indicate if changes were made. The images or other third party material in this article are included in the article's Creative Commons licence, unless indicated otherwise in a credit line to the material. If material is not included in the article's Creative Commons licence and your intended use is not permitted by statutory regulation or exceeds the permitted use, you will need to obtain permission directly from the copyright holder. To view a copy of this licence, visit http://creativecommons.org/ licenses/by/4.0/.

\section{References}

Bachman, S., Moat, J., Hill A. W., de la Torre, J. \& Scott, B. (2011). Supporting Red List threat assessments with GeoCAT: geospatial conservation assessment tool. In: V. Smith \& L. Penev (eds), eInfrastructures for data publishing in biodiversity science. ZooKeys 150: 117 - 126. Available from: http://geocat.kew.org/. [Accessed 19 July 2019].

, Field, R., Reader, T., Raimondo, D., Donaldson, J., Schatz, G. E. \& Nic Lughadha, E. M. (2019). Progress, challenges and opportunities for Red Listing. Biol. Conservation 234: 45 - 55.

Barthlott, W., Lauer, W. \& Placke A. (1996). Global distribution of species diversity in vascular plants: towards a world map of phytodiversity. Erkunde 50: 317 - 328 (with supplement and figure).

Brenan, J. P. M. (1952). Plants of the Cambridge Expedition, 1947 - 1948: II. A New Order of Flowering Plants from the British Cameroons. Kew Bull. 7 (2): 227 - 236. https:/ / doi.org/10.2307/4109266
Breteler, F. J. (2004). The genus Trichoscypha (Anacardiaceae) in Lower Guinea and Congolia: A synoptic revision. Adansonia 26 (1) $97-127$.

Bakker, F. T. \& Jongkind, C. C. H. (2015). A synopsis of Soyauxia (Peridiscaceae, formerly Medusandraceae) with a new species from Liberia. Pl. Ecol. Evol. 148: 409 - 419. https://doi.org/ $10.5091 /$ plecevo.2015.1040

Burkill, H. N. (1994). The Useful Plants of West Tropical Africa. Vol. 2, families E - I. Royal Botanic Gardens, Kew. https://doi.org/10.2307/4111051

Cable, S. \& Cheek, M. (1998). The plants of Mt Cameroon, a conservation checklist. Royal Botanic Gardens, Kew.

Cameroon data portal (2015). http:// cameroon.opendataforafrica.org/PHCC2015/population-and-housing-census-of-cameroon2015?tsId=1002400. [Accessed Oct. 2019].

Cheek, M. (continuously updated). The Tropical Important Plant Areas (TIPAs): Cameroon programme. https://www.kew.org/science/our-science/projects/tropical-important-plant-areas-cameroon. [Downloaded 6 Oct. 2019].

(1992). A Botanical Inventory of the Mabeta-Moliwe Forest. Report to Govt. Cameroon from O.D.A. Royal Botanic Gardens, Kew.

(2000). A synoptic revision of Ancistrocladus (Ancistrocladaceae) in Africa, with a new species from western Cameroon. Kew Bull. 55: 871 - 882. https://doi.org/10.2307/4113632

(2002). Three new species of Cola (Sterculiaceae) from western Cameroon, Cameroon. Kew Bull. 57: 402 - 415. https://doi.org/10.2307/4111117

(2004a). Drypetes preussii. The IUCN Red List of Threatened Species 2004: e.T34775A9888700. h t t p s : / / d o i . o r g / $10.2305 /$ IUCN.UK.2004.RLTS.T34775A9888700.en. [Downloaded 4 Oct. 2019].

(2004b). Drypetes magnistipula. The IUCN Red List of Threatened Species 2004: e.T45451A10999341. h t t p s : / / d o i.o r g / $10.2305 /$ IUCN.UK.2004.RLTS.T45451A10999341.en. [Downloaded 4 Oct. 2019].

(2004c). Afrothismia pachyantha. The IUCN Red List of Threatened Species 2004 : e.T39539A10246294. https://doi.org/10.2305/ IUCN.UK.2004.RLTS.T39539A10246294.en. [Downloaded 6 Oct. 2019].

\& Becker, R. (2004). A new species of Myosotis L. (Boraginaceae) from Cameroon, with a key to the Tropical African species of the genus. Kew Bull. 59: 227 - 231. https://doi.org/10.2307/4115854

\& Bridson, D. (2002). Two new species of Psychotria (Rubiaceae) from western Cameroon. Kew Bull. 57: 389 - 395. https://doi.org/10.2307/ 4111114 
\& Cable, S. (1997). Plant Inventory for conservation management: the Kew-Earthwatch programme in Western Cameroon, 1993 - 96. In: S. Doolan (ed.), African rainforests and the conservation of biodiversity: 29 - 38. Earthwatch Europe, Oxford.

\& (1998). Preliminary results of the botanical inventory of the Ekundu Kundu Region of the Korup Park, pp. 72 - 80. In: N. C. Songwe (ed.), Proceedings of Workshop on Korup National Park E Project Area. Korup Project, Mundemba, Cameroon.

\&__ (2000). Drypetes tessmanniana. The IUCN Red List of Threatened Species 2000:e.T39517A10243683. https://doi.org/ 10.2305 / I U CN. UK. 2000 . RLTS.T39517 A 10243683.en. [Downloaded 4 Oct 2019].

\& Csiba, L. (2002). A new epiphytic species of Impatiens (Balsaminaceae) from western Cameroon. Kew Bull. 57 (3): 669 - 674. https://doi.org/ $10.2307 / 4110997$

\& Dawson, S. (2000). A synoptic revision of Belonophora Hook. f. (Rubiaceae). Kew Bull. 55: 63 80. https://doi.org/10.2307/4117761

\& Etuge, M. (2009). A new submontane species of Deinbollia (Sapindaceae) from Western Cameroon and adjoining Nigeria. Kew Bull. 64: 503 - 508. https://doi.org/10.1007/s12225-009-9132-4

\& Fischer, E. (1999). A tuberous and epiphytic new species of Impatiens (Balsaminaceae) from Southwest Cameroon. Kew Bull. 54: 471 - 475. https://doi.org/10.2307/4115828

\& Hepper, F. N. (1994). Progress on the Mount Cameroon Rainforest Genetic Resources Project, in Wildlife Conservation in West Africa. Nigerian Field Society (UK) Occasional Paper No. 1: 15 - 19.

\& Lachenaud, O. (2013). Psychotria elephantina sp. nov. (Rubiaceae) an Endangered rainforest shrub from Cameroon. Nord. J. Bot. 31 (5): 569 - 573. https://doi.org/10.1111/j.1756-1051.2012.01488.x

\& Williams, S. (1999). A Review of African Saprophytic Flowering Plants, pp. 39 - 49. In: J. Timberlake \& S. Kativu (eds), African Plants. Biodiversity, Taxonomy $\mathcal{E}$ Uses. Proceedings of the 15th AETFAT Congress at Harare, Zimbabwe. Royal Botanic Gardens, Kew.

Achoundong, G., Onana, J.-M., Pollard, B., Gosline, G., Moat, J. \& Harvey, Y. B. (2006). Conservation of the Plant Diversity of Western Cameroon. In: S. A. Ghazanfar \& H. J. Beentje (eds), Taxonomy and ecology of African plants, their conservation and sustainable use. Proceedings of the 17th AETFAT Congress, Addis Ababa, Ethiopia: 779 - 791. Royal Botanic Gardens, Kew.

Cable, S., Hepper, F. N., Ndam, N. \& Watts, J. (1996). Mapping plant biodiversity on Mt. Cameroon. pp. 110 - 120. In: L. J. G. van der Maesen, X. M. van der Burgt \& J. M. van Medenbach de Rooy (eds), The Biodiversity of African Plants (Proceedings XIV AETFAT Congress). Kluwer. https://doi.org/ 10.1007/978-94-009-0285-5_16

, Etuge, M. \& Williams, S. (2019). Afrothismia kupensis sp. nov. (Thismiaceae), Critically Endangered, with observations on its pollination and notes on the endemics of Mt Kupe, Cameroon. Blumea 64 (1): 158 - 164. https://doi.org/10.3767/ blumea.2019.64.02.06

, Harvey, Y. \& Onana, J.-M. (2010). The Plants of

Dom, Bamenda Highlands, Cameroon, A Conservation Checklist. Royal Botanic Gardens, Kew. \& (2011). The Plants of Mefou Proposed

National Park, Yaoundé, Cameroon, A Conservation Checklist. Royal Botanic Gardens, Kew.

Mackinder, B. Gosline, G., Onana, J.-M. \& Achoundong, G. (2001). The phytogeography and flora of western Cameroon and the Cross RiverSanaga River interval. Syst. Geogr. Pl. 71: 1097 1100. https://doi.org/10.2307/3668742

, Nic Lughadha, E., Kirk, P., Lindon, H., Carretero, J., Looney, B., Douglas, B., Haelewaters, D., Gaya, E., Llewellyn, T., Ainsworth, M., Gafforov, Y., Hyde, K., Crous, P., Hughes, M., Walker, B. E., Forzza, R. C., Wong, K. M. \& Niskanen, T. (2020). New scientific discoveries: plants and fungi. Plants, People Planet 2: 371 - 388. https://doi.org/10.1002/ ppp3.10148

, Onana, J.-M. \& Pollard, B. J. (2000b). The Plants of Mount Oku and the Ijim Ridge, Cameroon, a Conservation Checklist. Royal Botanic Gardens, Kew. Pollard, B. J., Darbyshire, I., Onana, J.-M. \& Wild, C. (2004). The Plants of Kupe, Mwanenguba and the Bakossi Mountains, Cameroon: A Conservation Checklist. Royal Botanic Gardens, Kew.

Prenner, G., Tchiengué, B. \& Faden, R. B. (2018b). Notes on the endemic plant species of the Ebo Forest, Cameroon, and the new, Critically Endangered, Palisota ebo (Commelinaceae). Pl. Ecol. Evol. 151 (3): 434 - 441. https://doi.org/10.5091/ plecevo.2018.1503

Radcliffe-Smith, A. \& Faruk, A. (2000a). A new species of Drypetes (Euphorbiaceae) from Western Cameroon. Kew Bull. 55: 871 - 882. https:// doi.org/10.2307/4113635

, Thomas, D., Besong, J. B., Gartlan, S. \& Hepper, F. N. (1994). Mount Cameroon, Cameroon, pp. 163 - 166. In: S. D. Davies, V. H. Heywood \& A. C. Hamilton (eds), Centres of Plant Diversity: A Guide and Strategy for their Conservation. WWF/IUCN, Cambridge.

, Tsukaya, H., Rudall, P. J. \& Suetsugu, K. (2018a).

Taxonomic monograph of Oxygyne (Thismiaceae), rare achlorophyllous mycoheterotrophs with strongly disjunct distribution. PeerJ 6: e4828. https://doi.org/10.7717/peerj.4828

Williams, S. \& Etuge, M. (2003). Kupea martinetugei, a new genus and species of Triuridaceae 
from western Cameroon. Kew Bull. 58: 225 - 228. https://doi.org/10.2307/4119366

Courade, G. (1974). Commentaire des Cartes. Atlas Regional. Ouest 1. ORSTOM, Yaoundé.

Cribb, P. J. (1996). New species and records of orchids from West Africa. Kew Bull. 51: 353 - 364. https:// doi.org/10.2307/4119329

Darbyshire, I., Anderson, S., Asatryan, A., Byfield, A., Cheek, M., Clubbe, C., Ghrabi, Z., Harris, T., Heatubun, C. D., Kalema, J., Magassouba, S., McCarthy, B., Milliken, W., Montmollin, B. de, Nic Lughadha, E., Onana, J.-M., Sa1dou, D., Sarbu, A., Shrestha, K. \& Radford, E. A. (2017). Important Plant Areas: revised selection criteria for a global approach to plant conservation. Biodivers. Conservation 26: 1767 - 1800. https://doi.org/10.1007/s10531-017-1336-6

Pearce, L. \& Banks, H. (2011). The genus Isoglossa (Acanthaceae) in west Africa. Kew Bull. 66: 425 - 439. https://doi.org/10.1007/s12225-011-9292-x

Dawson, S. (2002). A New Species of Stelechantha Bremek. (Rubiaceae, Urophylleae) from Cameroon. Kew Bull. 57: 397 - 402. https://doi.org/ $10.2307 / 4111116$

Franke, T., Sainge, M. \& Agerer, R. (2004). A new species of Afrothismia (Burmanniaceae, tribe Thismieae) from the western foothills of Mt Cameroon. Blumea 49: 451 - 456. https://doi.org/ $10.3767 / 000651904 \times 484397$

Gosline, G., Cheek, M. \& Kami, T. (2014). Two new African species of Salacia (Salacioideae, Celastraceae). Blumea 59: 26 - 32. https://doi.org/ $10.3767 / 000651914 \times 682026$

\& Malécot, V. (2012). A monograph of Octoknema (Octoknemaceae - Olacaceae s.l.). Kew Bull. 66: 367 - 404. https://doi.org/10.1007/s12225-011-9293-9

Harris, D. J. \& Wortley, A. H. (2018). A monograph of Aframomum (Zingiberaceae). Syst. Bot. Monogr. 104: $1-204$. \& (2006). A new species of Drypetes (Putranjivaceae) from the Central African Republic. Edinburgh J. Bot. 62: 253 - 256. https://doi.org/ 10.1017/s096042860600059x

Harvey, Y., Pollard, B. J., Darbyshire, I., Onana, J.-M. \& Cheek, M. (2004). The Plants of Bali Ngemba Forest Reserve, Cameroon. A Conservation Checklist. Royal Botanic Gardens, Kew.

, Tchiengue, B. \& Cheek, M. (2010). The plants of the Lebialem Highlands, a conservation checklist. Royal Botanic Gardens, Kew.

Heywood. V. H. (2007). Medusandraceae. p. 205. In: V. H. Heywood, R. K. Brummitt, A. Culham \& O. Seberg (eds), Flowering plant families of the world. Royal Botanic Gardens, Kew.

Hoffmann, P. (2007). Putranjivaceae. pp. 270 - 271. In: V. H. Heywood, R. K. Brummitt, A. Culham \& O. Seberg (eds), Flowering plant families of the world. Royal Botanic Gardens, Kew.
Hooker, J. D. (1864). On the plants of the temperate regions of Cameroons Mountain and in islands in the bight of Benin collected by Gustav Mann, government botanist. J. Proc. Linn. Soc., Bot. 7: 171 - 240. https://doi.org/10.1111/j.10958312.1864.tb01067c.x

Hutchinson, J. (1912). Drypetes pp. 674 - 689. In: W. T. Thistleton-Dyer (ed.), Flora of Tropical Africa 5, Sect. 1, Part 4. Lovell Reeve, London.

IPNI (continuously updated). The International Plant Names Index. Available from: http://ipni.org/ [accessed March 2018].

IUCN (2012). IUCN red list categories: Version 3.1. IUCN Species Survival Commission, Gland and Cambridge.

Johnson, S. D., Griffiths, M. E., Peters, C. I. \& Lawes, M. J. (2009). Pollinators, "mustard oil" volatiles, and fruit production in flowers of the dioecious tree Drypetes natalensis (Putranjivaceae). Amer. J. Bot. 96 (2): 2080 2086. https://doi.org/10.3732/ajb.0800362

Keay, R. W. J. (1958). Euphorbiaceae. In: R. W. J. Keay (ed.), Flora of West Tropical Africa 1: 364 - 423. Crown Agents, London.

Kirschner, J. \& Cheek, M. (2000). New combinations in Tropical African Luzula sect. Luzula (Juncaceae). Kew Bull. 55: 899 - 903. https://doi.org/10.2307/ 4113636

Lachenaud, O. (2019). Révision du Genre Psychotria (Rubiaceae) en Afrique Occidentale et Centrale. Opera Bot. Belg. 17: 1 - 900.

Maisels, F. M., Cheek, M. \& Wild, C. (2000). Rare plants on Mt Oku summit, Cameroon. Oryx 34: 136 - 140.https://doi.org/10.1017/ s0030605300031057

Mwachala, G. \& Cheek, M. (2012). Dracaena mokoko sp. nov. (Dracaenaceae-Ruscaceae/Asparagaceae) a Critically Endangered forest species from Mokoko, Cameroon. Nord. J. Bot. 30: 389 - 393. https:// doi.org/10.1111/j.1756-1051.2011.01487.x

Nic Lughadha, E., Bachman, S. P. \& Govaerts, R. (2017). Plant Fates and States: Response to Pimm and Raven. Trends Ecol. Evol. 32: 887 - 889. https:// doi.org/10.1016/j.tree.2017.09.005

, Govaerts, R., Belyaeva, I., Black, N., Lindon, H., Allkin, R., Magill, R. E. \& Nicolson, N. (2016). Counting counts: Revised estimates of numbers of accepted species of flowering plants, seed plants, vascular plants and land plants with a review of other recent estimates. Phytotaxa 272: 82 - 88 . https://doi.org/10.11646/phytotaxa.272.1.5

Onana, J.-M. (2011). The vascular plants of Cameroon, a taxonomic checklist with IUCN Assessments. Royal Botanic Gardens, Kew.

\& Cheek, M. (2011). Red data book of the flowering plants of Cameroon, IUCN global assessments. Royal Botanic Gardens, Kew.

Pax, F. \& Hoffmann, K. (1922). Euphorbiaceae Phyllanthoideae - Phyllantheae - Drypetinae pp. 
227 - 280. In: A. Engler (ed.), Das Planzenreich IV, 147 XV (Heft 81).

Plants of the World Online (continuously updated). Facilitated by the Royal Botanic Gardens, Kew. Published on the Internet; http:// www.plantsoftheworldonline.org/ [Retrieved 5 Oct. 2019].

Quintanar, A., Harris, D. J. \& Barberá, P. (2020). A new species of Drypetes (Putranjivaceae) discovered by J. Léonard in the Democratic Republic of the Congo. Pl. Ecol. Evol. 153 (2): 312 - 320. https://protecteu.mimecast.com/s/o39ACAMx6fNOq1Zc9q8z4

Radcliffe-Smith, A. (1987). Euphorbiaceae (Part 1). In: R. M. Polhill (ed.), Flora of Tropical East Africa. Balkema, Rotterdam.

Smedmark, J. E. \& Bremer, B. (2011). Molecular systematics and incongruent gene trees of Urophylleae (Rubiaceae). Taxon 60: 1397 - 1406. https://doi.org/10.1002/tax.605015

Soltis, D. E., Clayton, J. W., Davis, C. C. et al. (2007). Monophyly and relationships of the enigmatic family Peridiscaceae. Taxon 56: $65-73$.

Sosef, M. S. M., Wieringa, J. J., Jongkind, C. C. H., Achoundong, G., Azizet Issembé, Y., Bedigian, D., Van Den Berg, R. G., Breteler, F. J., Cheek, M. \& Degreef, J. (2005). Checklist of Gabonese Vascular Plants. Scripta Bot. Belg. 35. National Botanic Garden of Belgium.

Tchouto, P., Edwards, I., Cheek, M., Ndam, N. \& Acworth, J. (1999). Mount Cameroon Cloud Forest.
Pp. 263 - 277. In: African Plants: Biodiversity, Taxonomy, and Uses. Royal Botanic Gardens, Kew.

Thiers, B. (continuously updated). Index Herbariorum: A global directory of public herbaria and associated staff. New York Botanical Garden's Virtual Herbarium. Available from: http://sweetgum.nybg.org/ih/ [Accessed March 2018].

Thomas, D. \& Cheek, M. (1992). Vegetation and plant species on the south side of Mount Cameroon in the proposed Etinde reserve. Report to Govt. Cameroon from ODA. Royal Botanic Gardens, Kew.

Turland, N. J., Wiersema, J. H., Barrie, F. R., Greuter, W., Hawksworth, D. L., Herendeen, P. S., Knapp, S., Kusber, W-H., Li D-Z., Marhold, K., May, T. W., McNeill, J., Monro, A. M., Prado, J., Price, M. J. \& Smith, G. F. (2018). International Code of Nomenclature for algae, fungi, and plants (Shenzhen Code) adopted by the Nineteenth International Botanical Congress Shenzhen, China, July 2017 (eds.). Regnum Veg. 159. Glashütten: Koeltz Botanical Books. https://doi.org/10.12705/ Code.2018

\section{Publisher's Note}

Springer Nature remains neutral with regard to jurisdictional claims in published maps and institutional affiliations. 